Please acknowledge as follows: Elke Krahmann, 'From State to Non-State Actors: The Emergence of Security Governance', in: Elke Krahmann, ed., New Threats and New Actors in International Security, 2005, New York: Palgrave Macmillan, pp.3-19, reproduced with permission of Palgrave Macmillan.

This extract is taken from the author's original manuscript and has not been edited. The definitive, published, version of record is available here: http://www.palgrave.com/page/detail/new-threats-and-new-actors-ininternational-security-ms-elke-krahmann/?K=9781403966971

\title{
From State to Non-State Actors: The Emergence of Security Governance
}

\author{
Elke Krahmann
}

Non-state threats and actors have become key factors in contemporary security. However, little research has been conducted on the relationship between the two. The aim of this book is to address this gap by examining the growing role of non-state actors - both as the cause of new security threats, such as civil war, transnational crime, terrorism, infectious diseases, and the proliferation of small arms, and as security providers, including non-governmental organizations (NGOs), private security companies, and international regimes.

Since the end of the Cold War the notion that the state is the primary unit of interest in security studies has increasingly been challenged. Statistics show that today many more people are killed by ethnic conflicts, HIV/AIDS, or the proliferation of small arms than by interstate wars. Moreover, non-state actors are progressively complementing states in the provision of security. This chapter suggests that both developments can be understood as part of a shift from "government" to "governance" in security. This shift is characterized by the changing nature of threats in contemporary world politics and the ways in which they are addressed. In particular, the following seeks to illustrate the emergence of a system of security governance in which the making and implementation of security policies is shared among overlapping networks of state and non-state actors at the national, regional, and global levels.

The concept of security governance can thus serve as an overarching theoretical framework for the contributions to this volume that brings together experts on new threats and new actors. It seeks to examine how private actors have become one of the main sources of insecurity in the contemporary world, but also how non-state actors play a growing role in combating these threats.

\section{New Threats and New Actors}

Many will assert that neither civil war, transnational crime, infectious diseases, or the proliferation of small arms are new phenomena, nor is the involvement of 
[4] non-state actors, such as NGOs and private firms, in security policy. Before one can turn to an analysis of the transformation of security since the end of the Cold War, it is therefore necessary to examine why this volume talks about "new" threats and "new" actors.

\section{Changing Threat Environment}

To understand the changing nature of threat in contemporary global security one needs to define what is understood as security threat. A general reading of the term suggests that a security threat can be defined as an event with potentially negative consequences for the survival or welfare of a state, a society, or an individual. However, already this simple attempt at defining a security threat indicates the complexity of the concept. First, this definition suggests that a security threat refers to a possible future event. Our assessment that something represents a threat thus depends very much on the probability attributed to an event. Some negative events might be considered to be so unlikely that they are not considered a security threat anymore, such as a civil war in the United States or a military conflict between the member states of the European Union. Second, a security threat is characterized by the intensity of its potential effects, i.e. whether it endangers the survival or merely the welfare of human beings. Some threats, such as infectious diseases and weapons of mass destruction affect the welfare and survival of humans in a very immediate manner. Others, such as threats to the environment or the livelihood of peoples, affect the survival of humans in a more indirect way. Third, a security threat is defined by the geographical scope of its effects. Nuclear war, for instance, not only poses a danger to entire regions, but to life on earth in general. Conversely, the effects of civil wars are commonly limited to states or sub-regions. Finally, the nature of a security threat can be classified by its object. Threats are be differentiated according to whether they are directed at a collective, such as a state, an ethnicity or a religious group, or at individuals.

The preceding analysis illustrates that a security threat is as much a subjective as an objective category. Some aspects of it, such as the intensity and scope of a particular threat, can be assessed on the basis of technical data and evidence. The reach of a ballistic missile, for instance, can be measured. Others, such as an assessment of the probability of an ethnic conflict or the use of weapons of mass destruction in a border conflict, are inherently subjective and based on an understanding of the individuals involved in taking these decisions.

As a consequence of the complexity and subjectivity of threat assessment, our understanding of what presents a security threat in the $21^{\text {st }}$ century has changed considerably. In particular, the end of the Cold War has led to a fundamental reassessment of key security threats. The following section examines some of the primary security concerns today.

\section{Contemporary Security Threats}

During the Cold War the primary national and international security threat indisputably was nuclear war between the United States and the Soviet Union. With the fall of the Berlin Wall in 1990 and the dissolution of the Warsaw Pact, this threat has suddenly disappeared. However, 
[5] rather than leading to a period of unprecedented security, it has been replaced in the minds of decision-makers and the general public by a multitude of new security threats, such as terrorism, the proliferation of weapons of mass destruction, civil war, and ethnic conflict.

What makes these the primary security threats of the new century? The above section has argued that what is a key security threat is inevitably based on subjective assessments. Thus, the end of the Cold War did not lead to the elimination of nuclear war between the major powers as the first and foremost security threat because of the dismantling of all their nuclear weapons. In fact in 2003, both the United States and Russia still retained between seven and eight thousand nuclear warheads. ${ }^{1}$ The threat of a global nuclear exchange has primarily decreased because of trust in the changed foreign policy imperatives of these two countries. Similarly, the degree to which new security threats such as terrorism are considered of prime importance today is not only dependent upon the proliferation of weapons of mass destruction which might be used in a terrorist attack, but also on subjective estimates of the probability of such action, likely targets, scope, and intensity.

The range of factors involved in defining a security threat make the ranking of threats a difficult and very political choice. Since the resources of governments and international organizations are limited, they have to decide whether to make a threat with limited scope and intensity, but high probability, a priority or a threat with global reach and deadly consequences, but a comparatively low likelihood.

Among the new security threats identified by contemporary governments, terrorism is the most limited in terms of intensity, i.e. the number of peoples directly affected by death or injury. Empirical data on the degree of threat posed by terrorism shows that terrorism causes relatively few deaths if compared to other security concerns such as interstate war, civil conflict, or infectious diseases. Even on a global scale, numbers of terrorist casualties varied merely between 12 and 704 per year from 1968 to $1997 .{ }^{2}$ In more recent years, the number of global deaths caused by terrorist attacks averages to less than two thousand annually. In addition, most terrorist attacks are very limited in their scope. Typically only people in the immediate neighborhood of an attack will be affected. However, since September 11, 2001 terrorist attacks have been attributed a growing likelihood. Moreover, recent data shows an increase in the lethality of individual terrorist incidents.

In the wake of September 11 there has also been a re-evaluation of the threat of international proliferation. The potential of weapons of mass destruction, that is chemical, biological, and nuclear weapons, reaching the hands of terrorist groups like al Qaeda has received particular attention. The sarin gas attacks by the Japanese Aum sect in Tokyo in 1995 and the anthrax letters mailed to Congress in 2001 have illustrated the relative ease with which chemical agents can be manufactured by amateurs. Equally likely is the development of nuclear weapons by countries such as North Korea or Iran. The scope and intensity of the danger posed by the use of weapons of mass destruction is very high. They can not only destroy cities, but also entire regions and countries. However, the likelihood of their deployment is unclear. Biological and chemical weapons are notoriously difficult to control, and nuclear weapons invite massive retaliation. Weapons of 
[6] mass destruction have rarely been used even by the most determined actors. ${ }^{3}$ Traditionally, nuclear weapons have primarily been obtained for defensive purposes. Indeed, the nuclear stalemate between the United States and the Soviet Union has been credited by some with the preservation of the "long peace" that characterized the Cold War in Europe. ${ }^{4}$ However, the actors who would employ weapons of mass destruction and the nature of these weapons appear to be changing. Suicide terrorists are presumably less concerned about their ability to control biological, chemical, and nuclear weapons and more willing to take the risks involved in using them. Moreover, weapons of mass destruction are becoming more easily obtainable and deployable. So-called "dirty bombs" of nuclear material do not require sophisticated knowledge or material and the United States is studying the development of a new class of low-yield nuclear weapons for use in limited warfare rather than as a deterrent. ${ }^{5}$

Statistically the most dangerous form of proliferation is the spread of small arms and light weapons. There are currently 600 million small arms and light weapons in circulation affecting every part of the world. Used in wars as well as homicide, small arms kill over half a million people per year. Moreover, during the 1990s, small arms emerged as the weapon of choice in 47 out of 49 major conflicts, most of them civil wars. ${ }^{6}$ The link between small arms proliferation and civil conflict is particularly lethal since the number of intrastate wars has been increasing progressively since $1945 .^{7}$

In the 1970s there were annually between 15 and 20 major civil conflicts per year, in the 1980s this had increased to between 20 and 30, and since the 1990s it lies between 25 and 35 . Conversely the number of interstate conflicts has been rarely above five per year during the same period. ${ }^{8}$ Civil war scores high in terms of scope and intensity as well. Civil war not only affects large regions from Africa to South America and South-East Asia, it also ranks high in terms of threats to both the survival and the welfare of the peoples involved with both immediate and long-term consequences to life and prosperity.

Nevertheless, the credit of being the deadliest threat in contemporary security does not go to any form of human conflict, but to HIV/AIDS. The threat from this disease is not geographically limited, it leads to death within on average ten years, and the probability of adult infection ranges between 0.1 percent in Australia, 0.5-0.7 percent in North America, and 7.5-8.5 percent in Sub-Saharan Africa. In 2003, three million people died of HIV/AIDS. ${ }^{9}$ Furthermore, because of the long gestation period of the illness, HIV/AIDS has serious effects on the well-being of the infected and their relatives.

The preceding sections have indicated that none of these contemporary security threats are "new". Concerning terrorism, proliferation, and civil war, data has been collected since the 1940 s or 1960s. Nevertheless, it can be argued that all of them have achieved a new quality. The following section examines what distinguishes the new security threats of today from those which dominated the Cold War era.

\section{Nature of the "New" Threats}

If a security threat is generally defined by its probability, scope, intensity, and object, the central security concerns of today are characterized by a number of changes in some of these dimensions that differentiate 
[7] them from the threat of interstate war that defined the theory and practice of international security during the Cold War period. In particular, the new security threats appear to have a higher probability, a more variable scope and intensity, and a new object. Moreover, all of them are transnational security threats challenging the authority and reach of individual states. Examining each of these aspects in turn, it can be suggested that although these threats are not entirely "new", they have a number of characteristics that set them apart from traditional security concerns of the last century and appear to be especially dangerous today.

One of the main features common among the security threats discussed in the preceding section is their higher probability. Although a nuclear war was considered the primary security threat of the Cold War period, its historical frequency was rather low. In the $20^{\text {th }}$ century, there was only in once instance, namely during World War II, when nuclear weapons were employed in a military conflict. What ensured the priority of nuclear war among security policy makers was not its likelihood based on previous experience, but rather its potentially devastating effects on the survival and welfare of peoples around the globe.

New threats, such as terrorism, transnational crime, civil conflicts, and HIV/AIDS are much more pervasive and probable. In comparison with interstate war, civil conflicts have not only been on average about five times more frequent, also has the number of internal conflicts been steadily increasing since the end of World War II, while the occurrence of intrastate war has been relatively stable. Similarly, the number of terrorist casualties appears to have been on the rise since the 1960 s reaching its peak with 4,548 in 2001.10 Although a latecomer, HIV/AIDS by far exceeds these numbers with a steady increase from two million deaths globally in 1999 to three million in 2003. ${ }^{11}$ The statistical chance of any individual being directly affected by one or several of these threats during their lives today is considerably higher than the threat of nuclear war has been during the Cold War period.

In addition, the new security threats are more diverse in terms of their scope and intensity and thus appear to be more difficult to assess. Many of the effects of civil war, transnational crime, terrorism, and HIV/AIDS are not immediately apparent, but can only be measured in the long term. Moreover, their consequences on the lives of peoples are frequently indirect. These consequences include the displacement of large sections of a population, the damaging of the economy, the shortening of life expectancies and the withholding of foreign investment.

The third and most critical common feature of contemporary security threats is the fact that they do not target states, but societies and individuals. The new threats, such as civil war, terrorism, and transnational crime, the proliferation of small arms and HIV/AIDS, are transnational. Using the same technologies and means of transport that have benefited the globalization of trade and finance these transnational security threats illustrate that global integration can not only lead to new opportunities, but also new dangers. Specifically their ability to cross national boundaries with little hindrance undermines the security provisions established by a system based on sovereign nation-states.

Transnational threats are particularly unsettling because they do not fit into the analytical frameworks that had been developed during the Cold War. 
[8] Governments and international organizations have had to realize that their established security arrangements, such as large standing armed forces and the protection of national borders, are unsuited for the fight against transnational threats. However, not only do governments have to adapt their strategies to address these security threats, national borders and sovereignty which provided the basis for national and international security in the past are now frequently proving an obstacle. Transnational threats are thus requiring a reconsideration of security and how it can be achieved. The following section suggests that non-state actors play a crucial role in this transformation.

\section{New Actors}

Non-state actors have not only contributed to the emergence of new security threats such as terrorism and transnational crime, they are also playing a growing role in the provision of security. This section examines the nature and capabilities of non-state actors which enables them to help address contemporary security threats either in collaboration with governments or independently.

\section{Types of Non-State Actors}

Non-state actors formally can be grouped into two categories--private actors and intergovernmental organizations. The former includes a variety of forms such as private companies, charities, local pressure groups, as well as national and international nongovernmental organizations. The latter refers to multilateral institutions formed by sovereign nation-states. This book focuses in particular on three types of actors that have become key actors in contemporary security: non-governmental organizations, private military companies, and international institutions.

Non-governmental organizations are one of the largest groups of non-state actors engaged in security. They are typically defined as voluntary, non-profit organizations that operate at the national, regional, and global levels. NGOs include multilateral associations, such as the International Red Cross, international organizations, such as Médecins sans Frontières, and a multitude of regional or national NGOs, such as the American Refugee Committee. As the following chapters will illustrate, NGOs contribute directly and indirectly to security by offering services such as humanitarian aid and conflict reconciliation or by lobbying governments and international organizations in areas such as arms control and HIV/AIDS research.

Private military companies are more limited in their number and services, but have proliferated exponentially since the end of the Cold War. Commonly, the literature on private military companies distinguishes three types of firms based on the services that they offer. ${ }^{12}$ The term "mercenary firms" has been employed to denote private military companies that provide private soldiers and directly engage in national or international conflicts such as Sandline International, which was involved in the civil wars in Angola or Sierra Leone. "Private military firms" has been used to refer to companies that offer military training and strategic advice such as the Virginia-based Military Professional Resources Inc. (MPRI), and "private security firms" has been used to describe firms which provide military support, including logistics, base maintenance, and transportation such as Halliburton. Typically, however, companies offer a range of services across these 
[9] categories and the terms private security and private military companies are therefore used interchangeably in this book.

Finally, the number and role of international regimes and organizations have expanded in global security since the Cold War. Both can be formally distinguished in that the term "international regimes" is most often used to refer to multinational institutions that take the form of intergovernmental agreements or treaties. Examples include non-proliferation regimes such as the Australia Group, the Missile Technology Control Regime, the Nuclear Suppliers Group, and the Wassenaar Agreement. International regimes typically do not have an institutional organization, but are directly implemented by the member states. Conversely, international organizations like the North Atlantic Treaty Organization, the United Nations, and the European Union have independent organizational and administrative capabilities.

\section{Characteristics of the "New" Actors}

As with the security threats identified above, neither non-governmental organizations nor private military companies or international organizations are in fact "new" actors. Nevertheless, it can be argued that all three types of actors have not only proliferated disproportionally over the past two decades, they have also significantly expanded their contribution to the making and implementation of security policies. NGOs, for instance, have become key actors in the provision of human security in the post-Cold War interventions in the former Yugoslavia, Somalia, and Iraq. Private military companies increasingly offer military support services for national armed forces well as in international peacekeeping since the mid1990s. International organizations, such as NATO and the European Union, have extended their functional and geographical scope since the fall of the Iron Curtain to include new members in Central and Eastern Europe and address a new range of security threats.

What makes NGOs, private military companies, and international regimes and organizations "new" actors in contemporary security is that they are challenging the "monopoly" of the nation-state in the legitimate provision of security that had developed over the past centuries and appears to have reached its prime during the Cold War. Today it is widely accepted that NGOs and international organizations play important roles in global security. Moreover, some of these actors lay claim to a higher legitimacy than states because they are not operating in the interest of a single nation. Most crucially, NGOs, private security companies, and international organizations appear to be more suited to address contemporary security threats because they can operate across state boundaries by building on national chapters and multilateral cooperation. Similarly, many governments have been forced to recognize that a system based on national sovereignty can be rather ineffective when it comes to fight transnational proliferation, crime, terrorism, or HIV/AIDS. Since the new security threats predominantly target individuals and not states, governments find that sub-state actors such as NGOs and private military companies can help provide security at this level. Moreover, because threats such as terrorism and the proliferation of small arms are operating transnationally, many nation-states accept that multilateral cooperation through international regimes or organizations has become more important. 
[10] The changing nature of security threats and actors is not only transforming the making and implementation of security policies, it also has serious implications for the theoretical analysis of security. In particular, these two interlinked developments suggest that the study of security needs to be broadened beyond the state as the primary unit of analysis--both in terms of its object and subject. The following section examines the widening and deepening of the concept of security and the emergence of security governance as a framework for the analysis of contemporary international relations.

\section{Implications for International Relations Theory}

Having its origins as a separate field of study in the last century, theorizing in international relations and security studies has crucially been influenced by the experience of the two world wars and the superpower confrontation that followed it. As a consequence, many theoretical approaches to security studies have tended to focus on the threat of nuclear war and the role of states and their alliances in maintaining international security. Since the end of the Cold War, interstate war appears to have been replaced by a multitude of new transnational security threats. Moreover, as the preceding sections have suggested, the making and implementation of security policies is becoming increasingly fragmented among a multiplicity of actors, including states, international organizations, NGOs, and private military companies. International relations theory has reflected these transformations through three developments in particular: the broadening of the notion of security, the emergence of the concept of security governance, and the analysis of transnational networks. This section examines each of these new theoretical developments in turn.

\section{Redefinition of Security}

Already in the 1980s some authors pointed out the need to reexamine the meaning of security. ${ }^{13}$ However, in particular since the end of the Cold War the concept of security has become increasingly contested in international relations theory. ${ }^{14}$ At the heart of this debate have been attempts to deepen and widen the concept of security from the level of the state to societies and individuals, and from military to non-military issues.

This challenge to the state-centric notion of security that had dominated the discipline builds upon the argument that the end of the superpower confrontation has significantly reduced the likelihood of interstate war, whereas the threat from civil war, transnational crime, terrorism, and infectious diseases appears to have increased. As has been outlined in the preceding sections, annually many more casualties are incurred by subnational and transnational threats than from major power conflicts. In 1999, for instance, about 32000 individuals were killed in interstate wars. However, more than 900 people were killed through terrorist attacks, up to 39000 were killed in civil conflicts, and no less than 2.8 million were killed by AIDS. ${ }^{15}$ The changing balance becomes even more striking in the data provided by the Stockholm International Peace Research Institute (SIPRI) which records on average thirty major conflicts per year between 1990 and 2000, yet SIPRI observed only eight interstate wars during the entire ten-year period. ${ }^{16}$ 
[11] Academics remain divided over the utility of a more inclusive notion of security. ${ }^{17}$ Stephen Walt, for instance, has argued that that broadening of the concept of security will "destroy its intellectual coherence and make it more difficult to devise solutions to any of these important problems"18. And Ole Wæver has warned that the "securitization" of an issue, i.e. it being identified as a national or international security issue, "tends to lead to specific ways of addressing it: threat, defense, and often state-centred solutions"19. Nevertheless, a broader understanding of security has by now come to be widely accepted not only in international relations theory, but also among policy makers. The field of international relations today includes an ever-increasing number of studies on environmental security, human security, and HIV/AIDS as a security issue. ${ }^{20}$ These studies argue that examining new security threats need not detract from the analysis of interstate war, but rather complements it. In fact, understanding the security effects of environmental degradation, underdevelopment, and diseases can help explain and resolve intrastate and interstate conflicts.

Moreover, by adopting a broad definition of security international relations theory responds to important changes in the security policy-making process. Politicians, the military, and the general public are increasingly recognizing that crime, terrorism, environmental degradation, and infectious diseases are endangering not only individual, but also national security. This transformation is widely reflected in the national security estimates in the United States and other countries. Moreover, international organizations, such as NATO and the Conference for Security and Cooperation in Europe for instance, have expanded the scope of their security functions to include the fight against terrorism, international peacekeeping, refugee resettlement, and the promotion of civil society among others. Even the European Union which was conceived of as an economic organization is defining a growing array of its concerns in terms of security, including immigration and development aid. ${ }^{21}$

\section{From Government to Security Governance}

At the same time as governments and international organizations have extended their security concerns, however, limited resources, lack of expertise in non-traditional areas of security, and divergent interests among the United States and European governments have facilitated the fragmentation of security policy making. As the following chapters will illustrate, in addition to national governments and international organizations, a variety of private actors ranging from charities to private security companies have emerged in local, regional, and global security dealing with issues such as humanitarian aid, human rights monitoring, refugees, and military protection. ${ }^{22}$

While in the area of security the relations between diverse groups of actors have traditionally been conceived in terms of alliances, the fragmented but overlapping networks which structure the collaboration among the growing range of state and non-state security actors are more adequately described by the concept of governance. Contrary to "government" which refers to a system of centralized political control within the state, "governance" denotes a fragmented mode of policy making that includes state and non-state actors at the subnational, national, and international levels. ${ }^{23}$ Gordenker and Weiss thus define global governance as 
[12] "efforts to bring more orderly and reliable responses to social and political issues that go beyond capacities of states to address individually. Like the NGO universe, global governance implies an absence of central authority, and the need for collaboration or cooperation among governments and others who seek to encourage common practices and goals in addressing global issues." 24

The characteristics of governance arrangements vary widely. Most are concentrated around sets of states that share specific geographic, economic, and cultural similarities. However, even within these sets, governance is fragmented among governmental and nongovernmental actors at the national and international levels. While states continue to play a central role in global governance, international organizations, NGOs, and multinational corporations increasingly participate in the formulation, implementation, and monitoring of international policies, rules and regulations. ${ }^{25}$ Moreover, in the absence of a central authority in the international system and shifting balances of power, the relationships between governmental and non-governmental actors at the national and international level are frequently complex and horizontal. ${ }^{26}$

Several factors that involve the emergence of new threats and new actors have been identified as causes for a shift from government to governance in security. The first factor has been budgetary pressures that have encouraged the outsourcing and privatization of state security functions in a bid for improved efficiency. ${ }^{27}$ The second factor is a growing awareness of global problems and new security threats, such as transnational crime, terrorism, and migration, which can only be resolved through international cooperation. ${ }^{28}$ The third factor is globalization, specifically increased transnational contact, which appears to be creating or exacerbating many of these problems. ${ }^{29}$

Specifically, the shift from government to governance in security can be observed in the fragmentation of political authority among state and non-state actors in seven key dimensions: geography, function, distribution of resources, interests, norms, decision-making, and policy implementation. ${ }^{30}$ With the help of these seven dimensions a framework for the analysis of policy-making arrangements can be established that distinguishes between "government" and "governance" as ideal types. This theoretical framework helps to conceptualize the emergence of security governance since end of the Cold War.

The first dimension suggests that government and governance can be distinguished in terms of the geographical scope of policy-making arrangements. Government can thus be defined as centralized modes of governing based on the state as the key unit, whereas governance is characterized by the fragmentation of political authority among regional, global, and transnational private entities. In security, geographical fragmentation has particularly involved the delegation of security functions from the state to the regional level, such as NATO and the EU, to the global level, such as the United Nations, and to private actors, such as NGOs and private security companies. ${ }^{31}$

The second dimension proposes that policy-making arrangements can very between functional centralization and differentiation. A shift to security governance is thus indicated by the issue-specific division of labor in recent international peacekeeping missions such as in the former Yugoslavia where the United 
[13] Nations or NATO provided military security, while NGOs dealt with humanitarian aid, and private security companies offered logistical support. ${ }^{32}$

The third dimension implies that the distribution of resources can also be understood in terms of centralization and fragmentation. In centralized arrangements all or most resources that are required for the making and implementation of policies are ideal-typically held or channeled by the government. Conversely, in fragmented governance arrangements resources are dispersed among a range of public and private actors who have to coordinate their efforts in order to resolve common problems. In global security, it can be argued, this dispersion of capabilities has been fostered by the broadening of the notion of security to include new issues such as refugees and the environment where non-state actors have accumulated considerable experience as well as by the increasing cost of a more comprehensive security policy.

The fourth dimension suggests in addition a distinction between centralized and differentiated interests. It contends that the underlying premise of central government is that individual preferences can and should be subordinated to the common interests, whereas the notion of governance implies an acceptance of the heterogeneous and sometimes conflicting nature of interests and seeks to ensure that each actor can pursue them as uninhibited as possible. The emergence of security governance can thus be identified in the weakening of the transatlantic alliance and a shift towards "coalitions of the willing" after the end of the Cold War. Both developments are a response to the more localized and long-term consequences of the new security threats that, in spite of their transnational repercussions, allow governments to resist direct involvement unless they believe their immediate security interests are concerned. In addition, the increasing number of non-state actors introduces new interests into the security policy-making process such as the religious or ethical imperatives of NGOs.

In addition, the fifth dimension identifies diverging norms underlying government and governance, either promoting a strong state or prioritizing the self-determination of public and private actors. Three norms have traditionally supported the central authority of the state visà-vis national and international actors: sovereignty, command and control, and the ideal of redistribution. The opposing principle of differentiation is represented in the increasing limitation of national sovereignty, self-government, and marketization. In security the weakening of the norm of national sovereignty could be particularly observed in the intervention in Kosovo to counter Serb "ethnic cleansing" as well as more recently in the war against Iraq. In both interventions, self-government and the commercialization of security have been growing features as illustrated by the involvement of NGOs in both countries and an estimated 15,000 private military personnel in Iraq. ${ }^{33}$

Finally, the difference between government and governance also applies to policy decision-making and implementation. Decision-making processes that are centralized within governments are typically hierarchical, democratic, and consensual. Governance, on the contrary, is defined by horizontal relations among state and non-state actors, negotiation, and structural inequality. Similarly, policy implementation in government is centralized, authoritative, and, if necessary, 
[14] coercive, while governance involves decentralized implementation, self-enforced policies, and voluntary compliance. In global security, the rise of governance is thus illustrated by the proliferation of non-state actors engaged in major international interventions and the emergence of civil-military cooperation (CIMIC) as a concept and policy making arrangement. ${ }^{34}$

\section{Governance and Networks}

Characteristic of the shift from government to governance is the development of new networked forms of coordination among state and non-state actors. Networks are defined as sets of actors who share an interest in a specific issue area and are linked to each other through stable formal or informal relations. ${ }^{35}$ They can include domestic, transnational, and international linkages. ${ }^{36}$ Moreover, networks allow for a mixture of relations ranging from hierarchical to horizontal, and from government to market. ${ }^{37}$ The basis of network relations is typically the exchange of information, money, political support, or commitments for cooperative behavior among the involved actors.

Networks are particularly suited for political coordination in global and security governance for several reasons. First, due to the inclusion and frequently dominance of informal relations, networks are flexible and can adapt comparatively quickly and easily to new actors or demands. While formal institutional linkages require considerable time and resources in order to be established in national law or international regimes, informal relations can be set up instantaneously among actors who have an interest in an exchange or collaboration on a particular issue. New actors can enter into these relations on the basis of their capabilities and open channels of communication. New issues or problems can be responded to by forming new networks among affected actors or by transforming existing networks in order to enlarge their scope or capabilities.

In security, new networks have thus emerged and old networks have been adapted in response to the end of the Cold War. A prime example of changing networks is the transatlantic security community. In particular, NATO has transformed from a collective defense to a collective security organization, expanded its functions from military defense to peacekeeping and peacemaking, and incorporated new members in Central and Eastern Europe first through informal relations and later through formal enlargement. Moreover, the Atlantic Alliance has established informal civil-military relations with NGOs and other private actors during its interventions in Bosnia and Herzegovina, and Kosovo. ${ }^{38}$ During each of these interventions new operation-specific networks have developed among state and non-state actors engaged in the region in order to coordinate their interests and functions such as the provision of military security, mine clearance, humanitarian aid, and reconstruction.

Second, by moving beyond traditional institutional relations among states or among state and non-state actors, networks can stretch across national boundaries and sovereignties. Networks thus can address transnational security threats such as terrorism, transnational crime, HIV/AIDS, and small arms proliferation more effectively. Often these networks involve formal cooperation in transnational organizations like Interpol or international regimes such as the Nuclear Suppliers Group. However, equally often they build on transnational private 
[15] linkages most notably within charitable federations such as the International Red Cross and Red Crescent Societies, Médecins sans Frontières, CARE, Amnesty International, or Human Rights Watch, which have national chapters in different countries, or collective organizations such as InterAction.

Third, through decentralization and horizontal relationships networks promote subsidiarity, i.e. the making and implementation of policies by those who are directly involved or affected. Networks thereby encourage the development of differentiated solutions for a complex world rather than the imposition of centrally directed, uniform policies. Moreover, networks foster the use of local knowledge and resources, which benefits the long-term advancement of affected communities. Finally, drawing on local groups, personnel, and assets is frequently more cost-efficient than using centralized capabilities. In security governance, states and international organizations such as the United Nations, thus increasingly attempt to develop "civil society" in the form of local or regional groups that can help with security issues and reconstruction after conflicts. In addition, NGOs and private military companies employ to a large degree local personnel wherever they are operating.

However, networks do not only develop among state and non-state actors concerned with providing security. Transnational crime, terrorism, and the proliferation of small arms increasingly also use networks as operating system. These "dark networks" 39 benefit from the same characteristics that help states and non-state actors to coordinate their efforts to combat these threats: flexibility, transnational relations, local knowledge, and efficiency. Similar pressures thus facilitate similar structures among new threats and new actors in security governance.

\section{Content of the Book}

To examine the complex relationship between new threats and new actors in contemporary security this book is divided into four parts: civil war, transnational crime and terrorism, HIV/AIDS, and the proliferation of small arms. The first part specifically examines the contribution of non-state actors to international peacekeeping. In chapter two, "The New Conflict Managers: Peacebuilding NGOs", Loramy Gerstbauer provides a compelling analysis of the emerging role of NGOs in conflict and post-conflict environments. She suggests that many relief and development organizations have come to realize the impact of their presence and their provision of aid in conflicts. Consequently, they have decided to add peacebuilding to their mandates. However, Gerstbauer points out, NGO conflict management activities are not uncontroversial. Just as development NGOs are interdependent with the government agencies that fund them, the new NGO mandate is heavily influenced by state interests in post conflict settings. This raises a number of dilemmas for NGOs ranging from the challenge of maintaining neutrality when working alongside or in cooperation with armed forces to balancing the influence and interests of donors and recipients.

In chapter three, "Humanitarians and Mercenaries: Partners in Security Governance?", Christopher Spearin picks up on this theme by analyzing the emerging partnership between peacebuilding NGOs and private security companies. 
[16] Particularly he raises the question whether the employment of private security by NGOs will lead to a new humanitarian order through which all those in need of assistance will receive aid promptly and effectively. Spearin argues that, although there are good reasons for this partnership, there are also a number of problems such as the image of the "mercenary" and the cost of private security. In the end a trade-off will have to be made.

The second part of the book turns to terrorism and transnational crime as key security threats for the new millennium and the contribution that private actors can make to address these threats. In chapter four, "Drug Trafficking, Terrorist Networks, and Ill-Fated Government Strategies", Michael Kenney offers a unique analysis of the similarities between terrorist networks and the transnational drug trade. As a consequence, Kenney explains, the existing "head hunting" approach to the war on terrorism threatens to repeat critical mistakes in the anti-drug initiatives of the 1990s. Specifically, Kenney argues that by focusing its military, law enforcement, and intelligence capabilities on a handful of organizations and individuals, the U.S. government runs the risk of weeding out the most notorious enterprises and providing opportunities for lesser known, more technologically sophisticated operations to materialize.

Chapter five "Targeting Money Laundering: Global Approach or Diffusion of Authority" by Eleni Tsingou explains why combating money laundering is central to contemporary security, notably as a means of undermining terrorist and transnational criminal activities. Yet, Tsingou argues, in particular private financial institutions perceive a tension between the cost of dealing with money laundering and the benefits of containing financial crime. Fostering private corporate responsibility in the form of self-regulation and the implementation of public policies thus becomes a central concern in security.

The third part of the book analyses HIV/AIDS as a global security threat and the role of non-governmental actors in addressing it. In chapter six, "HIV/AIDS: The International Security Dimensions", Stefan Elbe sets out convincingly why the global AIDS pandemic is no longer solely a health issue, but also contains human, national, and international security dimensions. Elbe contends that only by recognizing these security dimensions we can arrive at a more comprehensive understanding of the nature and extent of the contemporary AIDS pandemic and to develop suitable responses.

This analysis is complemented by chapter seven, "NGOs as Security Actors in the Fight against HIV/AIDS?", by Carrie Sheehan which examines how HIV/AIDS is addressed. Sheehan observes that there is currently a proliferation of NGOs working in developing countries on the HIV/AIDS pandemic. However, Sheehan illustrates that while many states, think tanks, and international organizations today perceive HIV/AIDS as an national and international security issue, NGOs do not. The result is a disconnection between the actors addressing the HIV/AIDS pandemic at the policy level and the, frequently non-state, actors implementing HIV/AIDS programs.

The final part of the book discusses the role of non-state actors in the proliferation of small arms and light weapons as well as their contribution to the establishment of effective non-proliferation regimes. Chapter eight, "The Proliferation of 
[17] Small Arms and Light Weapons", by Mike Bourne turns to small arms and light weapons (SALW) proliferation as a security threat and explains how non-state actors, such as brokers, transporters, transnational criminal organizations, as well as criminalized state officials contribute to the global spread of SALW. Bourne specifically highlights the collaboration between non-state and state actors in the spread of SALW and their diversion from the legal sphere into illicit circulation.

In chapter nine, "NGOs and the Shaping of the European Union Conventional Arms Regime", Holger Anders offers an insightful examination of how NGOs influenced the creation of the European Union regime on conventional arms. Anders argues that transnational networks of NGOs, researchers, and campaigners were able to shape public policies on small arms by consistently mobilizing and generating political and public support for their policy preferences, and by closely interacting with government officials across Europe. Thus, Anders demonstrates how non-state actors could facilitate and contribute to governmental policy coalitions, and insist on the inclusion of certain dynamic elements in the European regime.

The conclusion of this book seeks to summarize the findings presented in the preceding chapters and discusses the advantages and problems that have been identified with regard to the growing role of non-state actors in security and the collaboration between state and nonstate agents. It particular the conclusion raises the question whether the shift from government to governance is a suitable solution to the emergence of transnational security threats that cannot be addressed within the traditional system of nation states. Moreover, the conclusion discusses whether the growing influence of private actors a sign of the emergence of a global civil society or whether private actors are merely tools for state intervention.

\section{Notes}

\footnotetext{
${ }^{1}$ Hans M. Kristensen, "Russian Nuclear Forces," http://projects.sipri.se/nuclear/russia.pdf, and "US Nuclear Forces," http://projects.sipri.se/nuclear/usa.pdf.

2 RAND-MIPT, "Terrorism Database," http://db.mipt.org/.

${ }^{3}$ Instances include the use of mustard gas by Italy in World War I and Iraq against its Kurdish population between 1983 and 1988, the atom bomb by the United States in 1945, and various biological agents by Japan in World War II.

${ }^{4}$ John Lewis Gaddis, The Long Peace: Inquiries into the History of the Cold War (Oxford: Oxford University Press). John Mearsheimer has even suggested that nuclear proliferation could enhance post-Cold War security. See John Mearsheimer, "Back to the Future: Instability in Europe After the Cold War," International Security 15, no. 4 (1990): 5-56.

5 Paul Harris, "Bush Plans New Nuclear Weapons," Observer, November 30, 2003.

6 United Nations Small Arms Programme, http://disarmament.un.org:8080/cab/salw.html.

7 Heidelberg Institute on International Conflict Research, Conflict Barometer 2003, 5, http://www.hiik.de/en/barometer2003/Conflict_Barometer_2003.pdf.

8 Ibid.

9 World Health Organization (WHO), "AIDS Epidemic Update 2003,"

http://www.who.int/hiv/pub/epidemiology/imagefile/en/.

10 RAND-MIPT, "Terrorism Database," http://db.mipt.org/.

11 UNAIDS, AIDS Epidemic Update 2003 (Geneva: UNAIDS/WHO, 2003).

12 Peter W. Singer, "Corporate Warriors: The Rise and Ramifications of the Privatized Military Industry," International Security 26, no. 3 (2001): 186-220; Garry Cleaver, "Subcontracting Military
} 
Power: The Privatisation of Security in Contemporary Sub-Saharan Africa," Crime Law and Social Change 33, no. 1-2 (2000): 131-149.

${ }_{13}$ Richard H. Ullman, "Redefining Security," International Security 8, no. 1 (1983): 129-153.

${ }^{14}$ Stephen M. Walt, "The Renaissance of Security Studies," International Studies Quarterly 35, no. 2 (1991): 211-239; Emma Rothschild, "What is Security?" Daedalus 124, no. 3 (1995): 53-98; David A. Baldwin, David A., "The Concept of Security," Review of International Studies 23, no.1 (1997): 5-29. 15 UNAIDS, Report on the Global HIV/AIDS Epidemic (New York: UNAIDS, 2000), http://www.unaids.org/epidemic_update/report/glo_estim.pdf.

16 See SIPRI Yearbooks from 1991 to 2001 (Oxford: Oxford University Press).

17 Keith Krause and Michael C. Williams, eds. Critical Security Studies: Concepts and Cases (Minneapolis: University of Minnesota Press, 1997).

18 Walt, 213.

19 Ole Wæver, "Securitization and Desecuritization," in On Security, ed. Ronnie D. Lipschutz, 46-86 (New York: Columbia University Press, 1995), 65.

${ }^{20}$ See for instance Thomas Homer-Dixon, Environment, Scarcity, and Violence (Princeton, NJ:

Princeton University Press, 2001); B.R. Allenby, "Environmental Security: Concept and

Implementation," International Political Science Review 21, no. 1 (2000): 5-21; Roland Paris, "Human Security. Paradigm Shift or Hot Air?" International Security 26, no. 2 (2001): 87-102; Peter W. Singer, "AIDS and International Security," International Security 44, no. 1 (2002): 145-58.

${ }^{21}$ Ian Manners, European [Security] Union: From Existential Threat to Ontological Security, Working Paper No. 5 (Copenhagen: COPRI, 2002), http://www.copri.dk/publications/workingpapers.htm. 22 See for instance OXFAM, Oxfam International Annual Report 2002 (Oxford: Oxfam, 2002); ICRC (International Committee of the Red Cross), Annual Report 2002 (Geneva: ICRC, 2002); International Rescue Committee, International Rescue Committee Annual Report 2002-2003 (New York: International Rescue Committee, 2002); MRPI (Military Professional Resources Inc.), Overview, http://www.mpri.com/channels/int_overview.html.

${ }^{23}$ Ernst-Otto Czempiel, "Governance and Democratization," in Governance without Government: Order and Change in World Politics, eds. James N. Rosenau and Ernst-Otto Czempiel, 250-71 (Cambridge: Cambridge University Press, 1992), 250; Leon Gordenker and Thomas G. Weiss, "Pluralizing Global Governance: Analytical Approaches and Dimensions," in NGOs, the UN, and Global Governance, eds. Leon Gordenker and Thomas G. Weiss, 17-47 (London: Lynne Rienner, 1996), 17.

24 Gordenker and Weiss, 17. For similar definitions see Lawrence S. Finkelstein, "What Is Global Governance?" Global Governance 1, no. 3 (1995): 367-72, 368; Commission on Global Governance, Our Global Neighbourhood: The Report of the Commission on Global Governance (Oxford: Oxford University Press, 1995), 2-3; Oran Young, International Governance: Protecting the Environment in a Stateless Society (Ithaca, NY: Cornell University Press, 1994), 53.

25 James N. Rosenau, "Change, Complexity, and Governance in Globalizing Space," in Debating Governance. Authority, Steering and Democracy, ed. Jon Pierre, 167-200 (Oxford: Oxford University Press, 2000), 172-73; Commission on Global Governance, 2-3; Gearóid Ó Tuathail, Andrew Herod, and Susan M. Roberts, "Negotiating Unruly Problematics," in An Unruly World? Globalization, Governance and Geography, eds. Andrew Herod, Gearóid Ó Tuathail, and Susan M. Roberts, 1-24 (London: Routledge, 1998), 14.

26 Rosenau, 189; Finkelstein, 367; Gordenker and Weiss, 17.

27 Giandomenico Majone, "From the Positive to the Regulatory State: Causes and Consequences of Changes in the Mode of Governance," Journal of Public Policy 17, no. 2 (1997): 139-68, 142.

28 James N. Rosenau, "Governance, Order and Change in World Politics," in Governance without Government: Order and Change in World Politics, eds. James N. Rosenau and Ernst-Otto Czempiel, 129 (Cambridge: Cambridge University Press, 1992), 3; Tuathail et al., 12. 
${ }^{29}$ Gordenker and Weiss, 20; Bernard Zangl and Michael Zürn, "The Effects of Denationalisation on Security in the OECD World," Global Society 13, no. 2 (1999): 139-161, 140.

30 Elke Krahmann, "National, Regional and Global Governance: One Phenomenon or Many?" Global Governance 9, no. 3 (2003): 323-346.

${ }^{31}$ Damian Lilly, The Privatization of Security and Peacebuilding (London: International Alert, 2000); James N. Rosenau, "Change, Complexity, and Governance in Globalizing Space," in Debating Governance. Authority, Steering, and Democracy, ed. Jon Pierre, 169-200 (Oxford: Oxford University Press, 2000); Alexander Cooley and James Ron, "The NGO Scramble: Organizational Insecurity and the Political Economy of Transnational Action," International Security 27, no. 1 (2001): 5-39; Robert Mandel, Armies Without States: The Privatization of Security (Boulder, CO: Lynne Rienner, 2002). 32 Larry Minear, Ted van Baarda, and Marc Sommers, NATO and Humanitarian Action in the Kosovo Crisis, Occasional Papers (Providence: The Thomas J. Watson Jr. Institute for International Studies, 2000).

33 Peter W. Singer, "Warriors for Hire in Iraq", Brookings Institution, April 15, 2004, http://www.brook.edu/views/articles/fellows/singer20040415.htm; New York Times, "Families Find Iraq Earnings Carry a Price," April 15, 2004.

34 On Civil Military Cooperation in Kosovo see http://www.nato.int/sfor/cimic/cimic.htm; see also NATO, NATO Civil-Military Cooperation (CIMIC) Doctrine, AJP-09, 2000, http://63.104.169.22/PDF/AJP-09.pdf.

35 M.M. Atkinson and W. D. Coleman, "Policy Networks, Policy Communities and the Problems of Governance," Governance 5, no. 2 (1992): 154-80.

36 Margaret Keck and Kathryn Sikkink, Activists beyond Borders: Transnational Advocacy Networks in World Politics (Ithaca, NY: Cornell University Press, 1998); Elke Krahmann, Multilevel Networks in European Foreign Policy (Aldershot: Ashgate, 2003).

${ }^{37}$ Paul Kenis and Volker Scheider, "Policy Networks and Policy Analysis: Scrutinizing a New Analytical Toolbox", in Policy Networks. Empirical Evidence and Theoretical Considerations, eds. Bernd Marin and Renate Mayntz, 25-62 (Frankfurt/Main: Campus, 1991), 42.

38 "Cimic Reconstruction," NATO Review 49, no. 1 (2001): 21, http://www.nato.int/docu/review/2001/0101-06.htm.

39 Jörg Raab and H. Binton Milward, "Dark Networks as Problems," Journal of Public Administration Research and Theory 13, no. 4 (2003): 413-39. 